Antitrust Policy and Industrial Policy: A View from the U.S.

\author{
Lawrence J. White $^{*}$ \\ Stern School of Business \\ New York University \\ Lwhite@stern.nyu.edu
}

\author{
Presented at the \\ Second Lisbon Conference on \\ Competition Law and Economics \\ Lisbon, Portugal
}

November 15-16, 2007

Revised draft: January 14, 2008

Comments welcomed

Key words: antitrust; industrial policy; regulation

JEL codes: K21, L40, L51, L52

${ }^{*}$ During 1982-1983 the author was the Chief Economist of the Antitrust Division of the U.S. Department of Justice. 


\title{
Antitrust Policy and Industrial Policy: A View from the U.S.
}

\author{
Lawrence J. White \\ Stern School of Business \\ New York University \\ Lwhite@stern.nyu.edu
}

\section{Introduction}

Antitrust policy and industrial policy are almost always in an uneasy condition of coexistence with each other. This is especially true for Europe, where a longer and stronger tradition of formal state intervention in the economy and of a distrust of markets has crystallized into various forms of "industrial policy", often expressed as the support and protection of "national champions". ${ }^{1}$ Antitrust -- and especially antitrust with real enforcement -- has a more recent existence in Europe.

By contrast, in the United States, the tradition of antitrust extends back for over a century, and the faith in markets is stronger. It was no accident that the deregulation movement that reduced governmental regulation that had impeded competition in transportation, telecommunications, financial, and energy markets first began in the U.S. in the $1970 \mathrm{~s}^{2}$ and only subsequently spread to Europe. The U.S. has never embraced a formal "industrial policy," and the only time that such an embrace was seriously debated was in the late 1970s and the 1980s. ${ }^{3}$ This was a period when U.S. economic growth had slowed appreciably from the relatively rapid growth that had characterized the postwar 1946-1973 era, and there were widespread fears that a primary reliance on markets would

\footnotetext{
${ }^{1}$ For a discussion of European industrial policy, see, for example, Blais (1986) and Pelkmans (2006).

${ }^{2}$ For overviews, see Joskow and Rose (1989), Noll (1989), Joskow and Noll (1994), and Winston (1996, 2006).

${ }^{3}$ See, for example, Behrman (1984a), Lawrence (1984), McCraw (1986), and Thompson (1989).
} 
not be sufficient to revive a more vigorous growth environment for the U.S. economy. It was also a period when the Japanese model -- embodying large private enterprises (often characterized as "Japan, Inc."), backed explicitly or implicitly by the Japanese government -- was seen as a highly successful route to rapid economic growth (and Japanese exports to and investments in the U.S. were seen as major threats to the U.S. economy). ${ }^{4}$

Nevertheless, the absence of a formal embrace of industrial policy in the U.S. has not meant the total triumph of antitrust and competitive markets and the banishment of governmental intervention. Instead, in the U.S., as well as in other countries, there is a long tradition of governmental intervention -- often at the expense of competitive markets. Though the extent of governmental intervention in the early twenty-first century may be well below its peak of the 1930s, it remains a potent force in U.S. political economy -- on both the politics side and the economy side - and often remains in an uneasy compromise with antitrust.

This essay will be about that uneasy compromise. In Section II of this paper, we will first offer definitions of antitrust and of industrial policy, so as to clarify the discussion that follows. Then, in Section III, we provide some details about the major categories of governmental intervention that are at odds with the spirit and letter of antitrust policy in the U.S. Section IV provides some reflections on the reasons for these tensions and conflicts. Section V concludes.

\footnotetext{
${ }^{4}$ A flavor of the admiration of the Japanese model and the fears for the U.S. economy at that time can be found in Johnson (1982, 1984), McCraw (1986), and Uekusa and Ide (1986).
} 


\section{$\underline{\text { II. Defining Terms }}$}

Although the terms "antitrust" and "industrial policy" may be clear in some readers' minds, there is enough ambiguity and range of possibilities that it is worth offering some clarifying definitions.

\section{A. Antitrust policy.}

By antitrust policy, I mean policies that are intended to encourage competition in markets and encourage the allocative efficiency that generally comes with competition. ${ }^{5}$ These policies are generally aimed at preventing cartels or other joint efforts at price-fixing (or market allocation, or agreements on product attributes), preventing mergers where the consequence would be a significant lessening of competition, and preventing unilateral actions by a seller where the consequence would be a significant enhancement of the seller's market power. ${ }^{6}$ In the U.S., these policies are enunciated in the Sherman Act of 1890 and the Clayton Act of 1914 (and subsequent amendments to both Acts) and in a rich history of clarifying court decisions. ${ }^{7}$

It should be readily admitted that not all of U.S. antitrust policy has always been

\footnotetext{
${ }^{5}$ As will be seen in the discussion below, where there is seen to be a tension between allocative efficiency and apparent competition, antitrust policy in the U.S. has tended to favor allocative efficiency.

${ }^{6}$ Where a merger or a unilateral action that would have likely anticompetitive consequences would also appear to promise significant efficiencies, an obvious tension arises; see, for example, Williamson (1968). Because efficiencies are often easy to conjure and to promise and possibly hard to achieve after the fact, U.S. antitrust enforcement has tended to treat with skepticism the efficiency claims -- but the tension persists. See, for example, Baker (2004). Also, in principle, all of the antitrust provisions that are discussed in the text are equally applicable to buyers and the exercise of their actual or potential market power.

${ }^{7}$ Overviews of the U.S. antitrust laws can be found in various antitrust law texts, such as Areeda and Hovenkamp (2004), Areeda, Kaplow, and Edlin (2004), Sullivan and Hovenkamp (1999), Sullivan and Grimes (2006), and Hovenkamp (1999a, 1999b, 2005), and in economics writings such as Kwoka and White (1989, 1994, 1999, 2004a, 2009).
} 
competition-enhancing and/or efficiency-enhancing. At various times, populism and anti-bigness have been important themes, leading to legislation and legal decisions that favored small businesses for their own sake. ${ }^{8}$ Misguided concerns about vertical restraints (such as tying, exclusive dealing, territorial allocations, and resale price maintenance) have impeded effective competition as well as efficiency. ${ }^{9}$ Critics of U.S. antitrust policy have gone further and questioned more generally the efficiency and competitive consequences of the laws and their enforcement, ${ }^{10}$ and one critic describes antitrust as "industrial policy", with the anticompetitive implications that accompany such a label. ${ }^{11}$

Still, the mainstream consensus would surely describe antitrust policy in the U.S. -especially in its current guise -- as oriented toward competition, markets, and efficiency.

\section{B. Industrial policy.}

Defining "industrial policy" is not quite so easy. Consider the following possibilities:

-- "Industrial policy refers to a set of measures taken by a government and aiming at influencing a country's performance towards a desired objective." (Pitelis 2006, p. 435)

\footnotetext{
${ }^{8}$ The Robinson-Patman Act of 1936 (an amendment to the Clayton Act, which was intended to inhibit manufacturer price discrimination that would favor large retailers and which is still intact) and the Miller-Tydings Act of 1937 (which authorized states to legalize resale price maintenance, at the behest of small retailers who feared the lower prices of retail chains, and which was repealed in 1975) are notable pieces of legislation that were expressly designed to favor small business. The decisions by the U.S. Department of Justice (DOJ) and the Federal Trade Commission (FTC) to block mergers in the 1960s, supported by a string of Supreme Court decisions in that decade -- most notably Brown Shoe Co., Inc. v. U.S., 370 U.S. 294 (1962) -- were clearly aimed more at bigness than at realistic concerns about effective competition.

${ }^{9}$ See, for example, White (1989) and the discussions of vertical restraints that are found in Kwoka and White (1989, 1994, 1999, 2004a, 2009).

${ }^{10}$ See, for example, Crandall and Winston (2003) and, earlier, Bork (1978).

${ }^{11}$ See Armentano (1999, p. 25).
} 
-- "Industrial policy means the initiation and coordination of governmental activities to leverage upward the productivity and competitiveness of the whole economy and of particular industries in it." (Johnson 1984, p. 8)

-- "'Industrial policy' refers to all policies designed to affect the allocation of resources between and within sectors of the economy." (Lawrence 1986, p. 126)

-- "... the term industrial policy indicates the relationship between business and government on a microeconomic level..." (Wachter and Wachter 1981, p. 1)

-- "Industrial policies are concerned with promoting industrial growth and efficiency." (OECD 1975, p. 7)

At these broad levels of generalities, every country has an "industrial policy", and there is nothing exceptional about the concept. Indeed, it is the patchwork of U.S. policies that are in tension with U.S. antitrust policy that will be the focus of the next section of this paper.

At the same time, these broad descriptions do not reach the more distinct notion of industrial policy that was driving the debate in the 1970s and 1980s in the U.S. and that continues to be used in policy debates concerning industrial policy elsewhere: In this more distinct notion, industrial policy is a concerted, focused, conscious effort on the part of a government to encourage and promote a specific industry or sector with an array of policy tools that include subsidies or reduced taxes, trade protection, favorable regulation, forced mergers, protection from foreign takeovers, etc. This was the perception within the U.S. of Japanese policies during the 1970s and 1980s. ${ }^{12}$ It continues to be the perception of some European governments' policies of explicitly favoring "national champions" and of "picking winners" but also, possibly, "supporting losers". ${ }^{13}$

Thus, the following seems a better definition of this more specific notion of industrial policy:

\footnotetext{
${ }^{12}$ See, for example, Behrman (1984b), Chalmers (1982, 1984), and McCraw (1986).

13 See, for example, the discussion of French policy in Franko and Behrman (1984); see also Blais (1986) and Pelkmans (2006).
} 
-- "In current use, the term 'industrial policy' denotes the promotion of specific industrial sectors rather than industrialization overall... Industrial policies are direct, micro, and selective; they are an attempt by government to influence the decision making of companies or to alter market signals; thus they are discriminating... Industrial policy has sometimes sought to support the losers, delaying or retarding their decline; in other cases the goal is to succor or catalyze maturing sectors or to stimulate advancing sectors." (Driscoll and Behrman 1984, p. 5)

This latter sense of industrial policy is the one that the U.S. policy debate considered in the 1980s and, in the end, shied away from. But, as we will discuss below, the broader (albeit somewhat more vague) version of "industrial policy" remains alive and well in the U.S., as in all other countries. But, since antitrust policy is so well developed and promoted in the U.S., the tensions that arise between this well-developed antitrust policy and this persistent patchwork of other policies are worth exploring. ${ }^{14}$ It is to these tensions that this paper now turns.

\footnotetext{
${ }^{14}$ There is an ironic twist to the tension between antitrust and industrial policy that should be mentioned: For the U.S. telephone industry during much of the 1980s and 1990s - surely a key industry for the U.S. economy during this period - the structure and behavior of the industry was largely determined by a single antitrust suit and its settlement. The DOJ had filed suit in October 1974 to dismember AT\&T, so as to create more competition in long distance telephony and in telephone equipment manufacturing. The suit ended in January 1982 with a consent decree that granted almost everything that the DOJ had wanted: the dismemberment of AT\&T into seven local operating companies and a separate company (which retained the AT\&T company name) that undertook long distance and manufacturing operations. The administration of the decree was the responsibility of Federal District Court Judge Harold H. Greene. Until federal legislation in 1996 (The Telecommunications Act of 1996) created new law for the telephone industry, Judge Greene was effectively the administrator of U.S. "industrial policy" for this industry. For further discussion, see, for example, Noll and Owen (1994).
} 


\section{The Tensions}

Government in the U.S. does not always "speak with a single voice." Although antitrust, with its emphasis on competition and markets, is actively pursued by the federal government, ${ }^{15}$ it is far from a universally accepted policy across the U.S. political-economy landscape. Other policies that are in conflict with the letter and/or spirit of antitrust policy sometimes involve explicit exemptions from the antitrust laws, sometimes involve other federal laws and actions that are simply at odds with antitrust policy, and sometimes involve actions by the 50 state governments. These three categories will be explored in turn.

\section{A. Formal exemptions from the antitrust laws.}

The recently completed "Report and Recommendations" of the Antitrust Modernization Commission (2007, p. 378) identified over thirty statutory or judicial exemptions (or partial exemptions) from the antitrust laws. These include:

- Agricultural cooperatives;

- Fishing cooperatives;

- Insurance;

- Export associations;

- Cooperative research joint ventures;

- Newspaper joint ventures;

- Ocean shipping "conferences"; and

- Professional baseball.

In addition, in three federally regulated areas -- banking, telecommunications, and railroads --

${ }^{15}$ Most of the 50 states also have antitrust laws, which apply to intra-state economic activity. As is discussed below, the individual states pursue their own sets of anticompetitive policies, which are in conflict with their own antitrust laws as well as with the federal antitrust laws. 
mergers either require the approval of regulators as well as the relevant antitrust agency (this is true for banking and telecommunications) or the merger approval authority rests entirely with the regulator (railroads). ${ }^{16}$

\section{B. Federal actions that are at odds with the antitrust laws.}

Governmental actions that limit competition and/or distort the outcomes that markets would otherwise bring -- and that are not dealing with the health-safety-environment categories of externality/spillover effects or the information asymmetry problems of safety issues or of finance that antitrust is not equipped to address -- are clearly at odds with the spirit of the antitrust laws, even if there is no clear legal conflict. Thus, trade protection activities, such as tariffs and quotas on imports and anti-dumping measures, inhibit the ability of non-U.S.-based firms to compete with domestic producers and are thereby anticompetitive. Agricultural policies that subsidize and protect (and that sometimes inhibit competition among) U.S. farmers is another major category of policies that is at odds with antitrust policy. "Buy American" policies for government procurement are similarly distorting. Tax and/or subsidy provisions that selectively favor some industries over others and thereby distort allocative efficiency are not uncommon features of the U.S. legislative landscape. $^{17}$ In addition, the policies of the U.S. Department of Defense and of the National Aeronautics and Space Agency (NASA), in promoting technological development and usually doing it solely through U.S. companies, would also fit into this category.

Further, the formal regulatory regimes that have encompassed the transportation, telecommunications, energy, and financial sectors have -- especially in the past, less so in the present

\footnotetext{
${ }^{16}$ For a discussion of the railroad experience, see Kwoka and White (2004b).

17 A current "poster child" for such distortions are the current U.S. policies -- tax, subsidy, regulatory, and import protection -- that encourage the production and use of corn-based ethanol as a substitute for gasoline as a motor fuel.
} 
-- tended to inhibit competition among their regulated entities. ${ }^{18}$

\section{Actions by the 50 states.}

In areas of "traditional" regulation, such as transportation, telecommunications, and finance, to the extent that the regulated activities have involved intra-state transactions (rather than interstate), the 50 states have had the authority to limit competition. Thus, in the past (less so in the present), individual states have limited the ability of banks to establish branch networks (as well as preventing banks that are chartered in other states from establishing locations), limited competition among local trucking firms, and limited entry by intrastate long-distance telephone carriers.

It was only in the early 1940s that litigation addressed the general question of whether anticompetitive regulatory actions by the states were exempt from the reach of the federal antitrust laws; the issue was decided by the U.S. Supreme Court in $1943 .{ }^{19}$ That decision went in favor of the states. This exemption covers not only the regulatory actions of the states, but also the actions of private companies that are undertaken under those regulations. These exemptions apply, so long as the restraint on competition is "clearly articulated and affirmatively expressed as state policy" and is "actively supervised by the State itself." ${ }^{20}$ Thus, state licensing and restrictions on occupations and professions, though anticompetitive, escape the reach of the antitrust laws. ${ }^{21}$ Similarly, price regulation (and limits on entry) of local taxicab markets and other restrictions on local competition

${ }^{18}$ For overviews, see Joskow and Rose (1989), Noll (1989), Joskow and Noll (1994), and Winston (1993, 1998).

${ }^{19}$ The initial Supreme Court case was Parker v. Brown, 317 U.S. 341 (1943).

20 These criteria are enunciated in California Retail Liquor Dealers Association v. Midcal Aluminum, Inc., 445 U.S. 97, 105 (1980).

${ }^{21}$ For discussions of recent efforts by some states to protect "full-service" real estate agents from the competition that could be provided by "discount" real estate agents, see Hahn, Litan, and Gurman (2005) and White (2006a). 
are exempt.

As was noted above, the insurance industry is explicitly exempted from the reach of the federal antitrust laws and is also exempt from federal regulation. Instead, the industry is regulated by the 50 individual states, and distortionary price regulation in the property-casualty and title insurance areas is the norm across the states. $^{22}$

${ }^{22}$ See, for example, Joskow (1973), White (1984), Bradford (1998), and Harrington (2000). 


\section{$\underline{\text { IV. Discussion }}$}

U.S. antitrust policy has generally been more flexible in accommodating efficiencyenhancing restraints than is often recognized. Thus, the need for sports leagues to agree on rules that restrain some aspects of competition among the constituent teams, in order to enhance the overall quality of the "product" that is offered to fans, has been recognized and allowed. ${ }^{23}$ The ability of groups of firms -- for example, through trade associations -- to agree on technological standards has been allowed. ${ }^{24}$ And where the transactions costs of individual negotiations would arguably be too large -- as in the negotiations of composers and music publishers with various categories of performers and broadcasters -- antitrust has countenanced broad agreements among competitors. ${ }^{25}$

Further, U.S. antitrust has evolved in a direction that is increasingly tolerant of unilateral vertical restraints, where their effects are not to facilitate horizontal collusion or to enhance market power. $^{26}$

Nevertheless, antitrust policy does not try to address other forms of market failure, such as spillovers/externalities in the health-safety-environment areas, public goods problems, or asymmetric information problems (e.g., with respect to safety issues or in financial services). ${ }^{27}$ Consequently, even a fervent believer in antitrust policy would expect the enactment of other

23 See, for example, National Collegiate Athletic Association v. Board of Regents of the University of Oklahoma, 468 U.S. 85 (1984). For a discussion of that case, see Horowitz (1999).

${ }^{24}$ But the agreement cannot be a deliberate effort to give an advantage to some firms at the expense of, say, a "maverick". See Radiant Burners, Inc. v. Peoples Gas Light \& Coke Co., 364 U.S. 656 (1961); and American Society of Mechanical Engineers, Inc. v. Hydrolevel Corp., 456 U.S. 556 (1982).

${ }^{25}$ See Broadcast Music, Inc. v. Columbia Broadcasting System, Inc., 441 U.S. 1 (1979).

${ }^{26}$ See the discussions of vertical restraints in Kwoka and White (1989, 1994, 1999, 2004a, 2009).

${ }^{27}$ One clear instance in which antitrust policy refused to accommodate externality concerns can be found in Fashion Originators' Guild v. FTC, 312 U.S. 457 (1941). 
governmental policies -- in response to significant examples of these types of market failure problems -- that would supersede what a pure markets-oriented policy would yield.

It is clear, however, that much of the policy interventions that were described in Section III are not in the category of good-faith efforts to deal with these kinds of market failures. Instead, even though the interventions may sometimes be cloaked in the language of market failure, ${ }^{28}$ they often simply represent a "concentrated interest" or "capture" model of collective action: ${ }^{29}$ A small group of parties that care strongly about a specific opportunity for gain may be able to succeed in capturing the powers of government so as to benefit itself (i.e., seek rents successfully) at the expense of the members of the broader public who individually suffer only small losses and for whom the transactions costs of organizing to resist are too great. Accordingly, they do represent true conflicts and tensions with antitrust policy.

Further, even where policies are trying to address true externalities -- e.g., air pollution problems -- the traditional regulatory tools have involved inefficient "command and control" methods; and rent-seeking efforts (and successes), including those that inhibit or distort competition, have often been attracted to these regulatory actions. ${ }^{30}$ Thus, again, these policies are in conflict with antitrust -- in spirit, as well as in practice.

${ }^{28}$ For example, the corn-based ethanol program that was noted above has been promoted with arguments that refer to the negative spillovers/externalities that arise from gasoline usage.

${ }^{29}$ See, for example, Stigler (1971), Posner(1971, 1974), and Olson (1965).

${ }^{30}$ See, for example, Ackerman and Hassler (1981) and Crandall (1983a, 1983b). Similarly, the U.S. policies that have traditionally been applied to other negative externalities, such as the use of the electromagnetic spectrum (broadcast telecommunications) and the problems of over-fishing, have involved command-and-control regulation and the inhibition of entry and of competition. Only relatively recently have more pro-competitive policies, such as spectrum auctions and efforts to create quasi property rights in fish harvesting, been introduced in some areas. See, for example, White (2001, 2006b). 


\section{$\underline{\text { V. Conclusion }}$}

Antitrust is not the sole policy pursued by governments, and Pareto optimality is not the goal of any known government. Government policies in the U.S. are not exceptions to these statements.

Thus, in considering antitrust policy in the U.S. and the collection of other policies, which might loosely be called the U.S.'s informal industrial policy, the perception of conflicts, tensions, and tradeoffs is an accurate reflection of reality. However, the domain of competitive markets, and of the applicability of antitrust policy, has surely grown since the 1930s and even since the 1970s. But there is still room for considerably more growth in this domain. Cautious optimism is probably in order; but so is constant vigilance, since (as the recent corn-based ethanol experience vividly illustrates) the "concentrated interests" model remains ever powerful. 


\section{$\underline{\text { References }}$}

Ackerman, Bruce A. and William T. Hassler. Clean Air and Dirty Coal. New Haven, Conn.: Yale University Press, 1981.

Antitrust Modernization Commission, Report and Recommendations. Washington, D.C.: AMC, April 2007.

Areeda, Phillip E. and Herbert Hovenkamp, Fundamentals of Antitrust Law. New York: Aspen, 2004.

Areeda, Phillip E., Louis Kaplow, and Aaron S. Edlin, Antitrust Analysis: Problems, Text, Cases. New York: Aspen Publishers, 2004.

Armentano, Dominick T., Antitrust: The Case for Repeal, 2nd edn. Auburn, Ala.: Ludwig von Mises Institute, 1999.

Baker, Jonathan B., "Efficiencies and High Concentration: Heinz Proposes to Acquire Beech-Nut (2001)," in John E. Kwoka, Jr., and Lawrence J. White, eds., The Antitrust Revolution, 4th edn. New York: Oxford University Press, 2004, pp. 150-159.

Behrman, Jack N., "Industrial Strategies in the United States," in Robert E. Driscoll and Jack N. Behrman, eds., National Industrial Policies. Cambridge, Mass.: Oelgeschlager, Gunn \& Hain, 1984a, pp. 215-228.

Behrman, Jack N., "Japanese Industrial Policy: A View from Outside," in Robert E. Driscoll and Jack N. Behrman, eds., National Industrial Policies. Cambridge, Mass.: Oelgeschlager, Gunn \& Hain, 1984b, pp. 85-91.

Blais, Andres, "Industrial Policy in Advanced Capitalist Democracies," in Andres Blais, ed., Industrial Policy. Toronto: University of Toronto Press, 1986, pp. 1-53.

Bork, Robert H., The Antitrust Paradox: A Policy at War with Itself. New York: Basic Books, 1978.

Bradford, David F., The Economics of Property-Casualty Insurance. Chicago: University of Chicago Press, 1998.

Crandall, Robert W., Controlling Industrial Pollution: The Economics and Politics of Clean Air, Washington, D.C., Brookings, 1983a.

Crandall, Robert W. (1983b), "Clean Air and Regional Protectionism," Brookings Review, 2 (Fall), 17-20. 
Crandall, Robert W. and Clifford Winston, "Does Antitrust Improve Consumer Welfare? Assessing the Evidence," Journal of Economic Perspectives 17 (Fall 2003), pp. 3-26.

Driscoll, Robert E. and Jack N. Behrman, "Introduction," in Robert E. Driscoll and Jack N. Behrman, eds., National Industrial Policies. Cambridge, Mass.: Oelgeschlager, Gunn \& Hain, 1984, pp. 1-24.

Franco, Lawrence G. and Jack N. Behrman, "Industrial Policy in France," in Robert E. Driscoll and Jack N. Behrman, eds., National Industrial Policies. Cambridge, Mass.: Oelgeschlager, Gunn \& Hain, 1984, pp. 57-71.

Hahn, Robert W., Robert E. Litan, and Jesse Gurman, "Paying Less for Real Estate Brokerage: What Can Make It Happen?" Working Paper \#05-11, AEI-Brookings Joint Center for Regulatory Studies, June 2005; available at http://aei-brookings.org/admin/authorpdfs/redirectsafely.php?fname=../pdffiles/WP05-11_Final-4reposting.pdf

Harrington, Scott E., Insurance Deregulation and the Public Interest. Washington, D.C.: AEI Press, 2000.

Horowitz, Ira, "The Reasonableness of Horizontal Restraints: NCAA," in Kwoka, John E., Jr., and White, Lawrence J. (eds.), The Antitrust Revolution: The Role of Economics, 3rd edn., New York, Oxford University Press, 1999, pp. 202-219.

Hovenkamp, Herbert, Antitrust. St. Paul, Minn.: West Group, 1999a.

Hovenkamp, Herbert, Federal Antitrust Policy: The Law of Competition and its Practice. St. Paul, Minn.: West Group, 1999b.

Hovenkamp, Herbert, The Antitrust Enterprise: Principle and Execution. Cambridge, Mass.: Harvard University Press, 2005.

Johnson, Chalmers, MITI and the Japanese Miracle. Stanford, Calif.: Stanford University Press, 1982.

Johnson, Chalmers, ed., The Industrial Policy Debate. San Francisco: Institute for Contemporary Studies, 1984.

Joskow, Paul L., "Cartels, Competition, and Regulation in the Property-Liability Insurance Industry," Bell Journal of Economics 4 (Autumn 1973), pp. 365-427.

Joskow, Paul L. and Roger G. Noll, "Economic Regulation: Deregulation and Regulatory Reform during the 1980s," in Martin Feldstein, ed., American Economic Policy in the 1980s. Chicago: 
University of Chicago Press, 1994, pp. 367-440.

Joskow, Paul L. and Nancy L. Rose, "The Effects of Economic Regulation," in Richard Schmalensee and Robert D. Willig, eds., Handbook of Industrial Organization, vol. 2. Amsterdam: North Holland, 1989, pp. 1449-1506.

Kwoka, John E., Jr., and Lawrence J. White, eds., The Antitrust Revolution. Glenview, Ill.: Scott, Foresman, 1989.

Kwoka, John E., Jr., and Lawrence J. White, eds., The Antitrust Revolution: The Role of Economics, 2nd edn. New York: HarperCollins, 1994

Kwoka, John E., Jr., and Lawrence J. White, eds., The Antitrust Revolution: Economics, Competition, and Policy, 3rd edn. New York: Oxford University Press, 1999.

Kwoka, John E., Jr., and Lawrence J. White, eds., The Antitrust Revolution: Economics, Competition, and Policy, 4th edn. New York: Oxford University Press, 2004a.

Kwoka, John E., Jr., and Lawrence J. White, "Manifest Destiny? The Union Pacific and Southern Pacific Railroad Merger (1996)," in John E. Kwoka, Jr., and Lawrence J. White, eds., The Antitrust Revolution: Economics, Competition, and Policy, 4th edn. New York: Oxford University Press, 2004b, pp. 27-51.

Kwoka, John E., Jr., and Lawrence J. White, eds., The Antitrust Revolution: Economics, Competition, and Policy, 5th edn. New York: Oxford University Press, 2009 (forthcoming).

Lawrence, Robert Z., Can America Compete? Washington, D.C.: Brookings Institution, 1984.

Lawrence, Robert Z., "Industrial Policy in the United States and Europe: Economic Principles and Political Practices," in Hiromichi Mutoh, Sueo Sekiguchi, Kotaro Suzumura, and Ippei Yamazawa, eds., Industrial Policies for Pacific Economic Growth. Boston: Allen \& Unwin, 1986, pp. 126-146.

McCraw, Thomas K., ed., America versus Japan. Boston: Harvard Business School Press, 1986.

Noll, Roger G., "Economic Perspectives on the Politics of Regulation," in Richard Schmalensee and Robert D. Willig, eds., Handbook of Industrial Organization, vol. 2. Amsterdam: North Holland, 1989, pp. 1253-1287.

Noll, Roger G., and Owen, Bruce M. "The Anticompetitive Uses of Regulation: United States v. AT\&T (1982)," in John E. Kwoka, Jr., and Lawrence J. White, eds., The Antitrust Revolution: The Role of Economics, 2nd edn. New York: HarperCollins, 1994, pp. 328-375.

Olson, Mancur, Jr., The Logic of Collective Action: Public Goods and the Theory of Groups. 
Cambridge, Mass.: Harvard University Press, 1965.

Organization for Economic Development and Cooperation, Objectives and Instruments of Industrial Policy: A Comparative Study. Paris: OECD, 1975.

Pelkmans, Jacques, "European Industrial Policy," in Patrizio Bianchi and Sandrine Labory, eds., International Handbook on Industrial Policy. Cheltenham: Edward Elgar, 2006, pp. 45-78.

Pitelis, Christos N., "Industrial Policy: Perspectives, Experience, Issues," in Patrizio Bianchi and Sandrine Labory, eds., International Handbook on Industrial Policy. Cheltenham: Edward Elgar, 2006, pp. 435-449.

Posner, Richard A., "Taxation by Regulation," Bell Journal of Economics and Management Science, 2 (Spring 1971), pp. 22-50.

Posner, Richard A., "Theories of Economic Regulation," Bell Journal of Economics and Management Science, 5 (Autumn 1974), pp. 335-358.

Stigler, George, J., "The Theory of Regulation," Bell Journal of Economics and Management Science, 2 (Spring 1971), pp. 3-21.

Sullivan, E. Thomas and Herbert Hovenkamp, Antitrust Law, Policy and Procedure: Cases, Materials, Problems. Charlottesville, Va.: Lexis Publishing, 1999.

Sullivan, Lawrence A. and Warren S. Grimes, The Law of Antitrust: An Integrated Handbook. St. Paul, Minn.: Thomson/West, 2006.

Thompson, Grahame, "The American Industrial Policy Debate: Any Lessons for the UK?" in Grahame Thompson, ed., Industrial Policy: USA and UK Debates. London: Routledge, 1989, pp. 11-83.

Uekusa, Masu and Hideki Ide, "Industrial Policy in Japan," in Hiromichi Mutoh, Sueo Sekiguchi, Kotaro Suzumura, and Ippei Yamazawa, eds., Industrial Policies for Pacific Economic Growth. Boston: Allen \& Unwin, 1986, pp. 147-169.

Wachter, Michael L. and Susan M. Wachter, "Introduction," in Michael L. Wachter and Susan M. Wachter, eds., Toward a New Industrial Policy? Philadelphia: University of Pennsylvania Press, 1981, pp. 1-5.

White, Lawrence J., "The Title Insurance Industry, Reverse Competition, and Controlled Business -A Different View," Journal of Risk and Insurance, 51 (June 1984), pp. 308-319.

White, Lawrence J., "The Revolution in Antitrust Analysis of Vertical Relationships: How Did We 
Get from There to Here?" in Robert J. Larner and James W. Meehan, eds., Economics and Antitrust Policy. New York: Quorum, 1989, pp. 103-121.

White, Lawrence J., "'Propertyzing' the Electromagnetic Spectrum: Why It's Important, and How to Begin," in Jeffrey A. Eisenach and Randolph J. May, eds., Communications Deregulation and FCC Reform: Finishing the Job. Boston: Kluwer, 2001, pp. 111-143; reprinted in Media Law \& Policy, 9 (Fall 2000), pp. 19-48.

White, Lawrence J., "The Residential Real Estate Brokerage Industry: What Would More Vigorous Competition Look Like?" Real Estate Law Journal, 35 (Summer 2006a), pp. 11-32.

White, Lawrence J., "The Fishery as a Watery Commons: Lessons from the Experiences of Other Policy Areas for U.S. Fisheries Policy,” Working Paper \#EC-06-18, Stern School of Business, New York University, November 2006b; available at: http://w4.stern.nyu.edu/emplibrary/6-18_White.pdf

Williamson, Oliver E. "Economies as an Antitrust Defense: The Welfare Tradeoffs." American Economic Review 58 (March 1968), pp. 18-36.

Winston, Clifford, "Economic Deregulation: Days of Reckoning for Microeconomists," Journal of Economic Literature, 31 (September 1993), pp. 1263-1289.

Winston, Clifford, "U.S. Industry Adjustment to Economic Deregulation," Journal of Economic Perspectives, 12 (Summer 1998), pp. 89-110. 